Rahmiyanti, et al/Jurnal Ekonomi Syariah Teori dan Terapan Vol. 6 No. 12 Desember 2019: 2381-2392; PENGARUH VARIABEL MAKROEKONOMI DAN INDEKS SAHAM INTERNASIONAL TERHADAP INDEKS SAHAM JAKARTA ISLAMIC INDEX (JII)

\title{
PENGARUH VARIABEL MAKROEKONOMI DAN INDEKS SAHAM INTERNASIONAL TERHADAP INDEKS SAHAM JAKARTA ISLAMIC INDEX (JII)'
}

\author{
Devi Rahmiyanti \\ Departemen Ekonomi Syariah-Fakultas Ekonomi dan Bisnis- Universitas Airlangga \\ Email: devi.rahmiyanti-2015@feb.unair.ac.id \\ Bayu Arie Fianto \\ Departemen Ekonomi Syariah-Fakultas Ekonomi dan Bisnis- Universitas Airlangga \\ Email : bayu.fianto@feb.unair.ac.id
}

\begin{abstract}
:
This study investigate the effect of macroeconomic variables and international stock index on the stock index Jakarta Islamic Index (JII) using monthly data over period January 2013 to December, 2018. Macroeconomic variables used in this study are inflation, exchange rate, international crude oil price, World Gold Price and for the international stock index using Dow Jones Islamic Market. The study employs the eror correction model (ECM). The empirical result reveal that there is co-integration between the four macroeconomic variables, one international stock index and stock index in Jakarta Islamic Index indicating long run equilibirium relationship. Furhther, the result reveal that with significancy $0,5 \%$ only exchange rate, international crude oil price, world gold price had significant effect on Jakarta Islamic Index while inflation and Dow jones Islamic Market did not have a significant effect on Jakarta Islamic Index.
\end{abstract}

Keywords: The stock Index, the Jakarta Islamic Index, the macroeconomic variables

\section{PENDAHULUAN}

Pasar modal syariah dimulai sejak munculnya instrumen pasar modal yang menggunakan prinsip syariah yakni reksadana syariah oleh PT. Danareksa Investment Management pada 3 Juli 1997 (Mannan, 2009). Kemudian Bapepam bersama Dewan Syariah Nasional dan Majelis Ulama Indonesia (DSN-MUI) melakukan Memorandum of Understanding (MoU) yang menunjukkan adanya kesepahaman antara keduanya untuk mengembangkan pasar modal berbasis syariah di Indonesia pada tanggal 14 Maret 2003 (OJK).

Kondisi pasar modal dicerminkan melalui Indeks Harga Saham yang menggambarkan pergerakan harga saham
(Abdalloh, 2018). Saham-saham yang masuk dalam kategori syariah salah satunya diwakili oleh indeks saham Jakarta Islamic Index (JII). JII ditetapkan sebagai benchmark pasar modal syariah tepatnya 3 Juli 2000 oleh BEl yang bekerja sama dengan PT . Dana Investemen Management. JII merupakan salah satu indeks menggambarkan pergerakan harga saham syariah yang terdiri dari 30 saham syariah (Soemitra, 2009).

Gambar 1.1 menunjukkan indeks JII mengalami fluktuatif. Menurut Wahyudi \& Sani (2014) menjelaskan terdapat hal-hal yang dapat mempengaruhi pergerakan indeks saham dikarenakan sejalan dengan era globalisasi, goncangan yang terjadi dalam perekonomian suatu negara akan

\footnotetext{
1 Jurnal ini merupakan bagian dari skripsi yang ditulis oleh Devi Rahmiyanti, NIM: 041511433126, yang diuji pada 21 Oktober 2019.
} 
Rahmiyanti, et al/Jurnal Ekonomi Syariah Teori dan Terapan Vol. 6 No. 12 Desember 2019: 2381-2392; PENGARUH VARIABEL MAKROEKONOMI DAN INDEKS SAHAM INTERNASIONAL TERHADAP INDEKS SAHAM JAKARTA ISLAMIC INDEX (JII)

berdampak pada negara lainnya yang saling terkait.

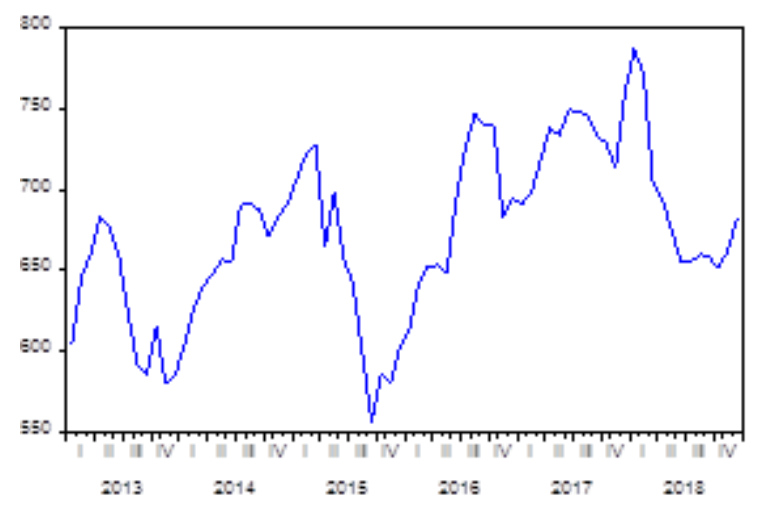

Sumber: (Bursa Efek Indonesia, 2019)

Gambar 1.

\section{Grafik Harga Saham JII Periode 2013-2018}

Hal itu ditunjukkan ketika ekonomi domestik (dalam negeri) terintegrasi dengan ekonomi global (luar negeri) yang akan menjadikan ekonomi suatu nagara menjadi rentan terhadap gejolak yang terjadi pada ekonomi global. Sehingga pasar saham tidak hanya dipengaruhi oleh kondisi ekonomi dan fenomena yang terjadi dalam negeri, melainkan pula gejolak ekonomi yang terjadi diluar negeri.

Dari sisi investasi asing, indek saham internasional syariah pertama yaitu DJIM. DJIM merupakan indeks saham yang meliputi saham-saham dari 34 negara, serta mencakup 10 sektor ekonomi, 18 sektor pasar, 51 kelompok industri dan 89 subkelompok industri (Beik \& Fatmawati, 2015). indeks DJIM dapat dijadikan sebagai indiktor untuk melihat bagaimana performa pasar modal syariah mengingat pasar saham syariah dapat dipengaruhi oleh gejolak yang terjadi di pasar saham internasional sebagai akibat semakin terintegrasinya pasar-pasar saham yang ada di dunia (Beik \& Fatmawati, 2015).

Selain dari sisi investasi asing, variabel makroekonomi yang berdampak langsung pada perekonomian suatu negara juga menjadi suatu pertimbangan. Menurut Beik dan Fatmawati (2015) berpendapat bahwa harga saham ditentukan oleh beberpa variabel makro, hal tersebut dikarenakan investor umumnya percaya bahwa peristiwa makroekonomi memiliki pengaruh besar terhadap pergerakan harga saham yang mempengaruhi keputusan investor dalam berinvenstasi. Menurut Tangjitprom (2012) menyatakan bahwa variabel makroekonomi yang mempengaruhi saham dapat diklasifikasikan ke dalam beberapa kelompok diantaranya terdapat inflasi, nilai tukar, harga minyak dunia, maupun harga emas dunia.

Dari uraian diatas bahwa variabelvariabel yang mempengaruhi indeks saham JII cukup beragam. Hal tersebut dikarenakan dalam ruang lingkup bisnis,faktor diluar perusahaan dapat mempengaruhi kinerja pada suatu perusahaaan baik secara langsung maupun tidak langsung (Samsul, 2006). Dengan kata lain, perubahan yang terjadi pada faktor ekonomi akan mempengaruhi para investor untuk mengambil suatu keputusan terkait saham yang akan dibeli ataupun dijual (Wahyudi \& Sani, 2014).

Ketika perubahan itu terjadi, investor akan mengkalkulasikan dampaknya baik positif maupun negatif yang nantinya akan mempengaruhi keputusan saham terkait 
Rahmiyanti, et al/Jurnal Ekonomi Syariah Teori dan Terapan Vol. 6 No. 12 Desember 2019: 2381-2392; PENGARUH VARIABEL MAKROEKONOMI DAN INDEKS SAHAM INTERNASIONAL TERHADAP INDEKS SAHAM JAKARTA ISLAMIC INDEX (JII)

(Samsul, 2006). Keputusan investor terkait saham inilah yang akan menghasilkan perubahan harga saham, dan pada akhirnya mempengaruhi indeks di pasar saham (Wahyudi \& Sani, 2014).

Kemungkinan investor tidak dapat memprediksi harga saham dikarenakan kondisi perkonomian yang tidak dapat dihindari dan keadannya bisa berubah sewaktu-waktu. Olah karena itu, perubahan yang terjadi pada harga saham dapat dipengaruhi oleh kondisi perekonomian yang tidak menentu. Dengan begitu, amatlah penting menjelaskan bagaimana variabel makro ekonomi dapat mempengaruhi Jakarta Islamic Index.

Beberapa penelitian telah mencoba untuk menjelaskan variabel yang mempengaruhi indeks saham syariah. Namun tinjauan literatur antara variabel makroekonomi dan indeks saham menunjukkan adanya pandangan yang berbeda diantara para peneliti terkait hubungan antara kedua variabel. Perbedaan ini disebabkan oleh kondisi ekonomi setiap negara dan daya tanggap setiap negara terhadap integrasi global yang berbeda. Maka terkait akan hal tersebut, penelitian ini dilakukan.

\section{II. \\ LANDASAN \\ TEORI \\ PENGEMBANGAN HIPOTESIS}

Investasi yaitu menanamkan atau menempatkan aset baik berupa harta maupun dana, pada sesuatu yang diharapkan akan memberikan hasil pendapatan atau akan meningkat nilainya di masa mendatang (Yuliana, 2010). Salah satunya pada pasar modal syariah, menurut Fatwa Dewan Syariah Nasional No.40/DSNMUI/X/2003 adalah pasar modal yang seluruh mekanisme kegiatannya terutama mengenai emiten, jenis efek yang diperdagangkan dan mekanisme perdagangannya telah sesuai dengan prinsip syariah. Efek syariah yang dimaksud adalah efek yang akad, pengelolaan perusahaan dan cara penerbitannya memenuhi prinsip syariah (DSN-MUI, 2019). Diantara efek syariah yang ada yaitu saham syariah.

Salah satu indeks saham syariah pertama di Indonesia yaitu Jakarta Islamic Index (JII). JII merupakan indeks saham yang melakukan penyeleksian terlebih dahulu terhadap saham yang ada dan ditetapkan 30 saham syariah yang paling likuid di BEl. Adapun evaluasi terhadap saham dilakukan setap 6 bulan sekali.

Merujuk pada paparan sebelumnya pada bab 1, terdapat hubungan antara harga saham dengan keadaan perekonomian suatu negara baik dalam negeri maupun luar negeri. Jll pada penelitian ini diasumsikan terpengaruh dari beberapa variabel makroekonomi dan indeks saham lain yaitu Diantaranya inflasi, nilai tukar, harga minyak dunia, harga emas dunia, dan DJIM.

Menurut Dobursch dkk (2008) dalam Wahyudi dan Sani (2014) menjelaskan bahwa makroekonomi merupakan interaksi antara pasar tenaga kerja dan barang pasar, dan pasar aset ekonomi serta interkasi antar negara dalam kegiatan 
Rahmiyanti, et al/Jurnal Ekonomi Syariah Teori dan Terapan Vol. 6 No. 12 Desember 2019: 2381-2392; PENGARUH VARIABEL MAKROEKONOMI DAN INDEKS SAHAM INTERNASIONAL TERHADAP INDEKS SAHAM JAKARTA ISLAMIC INDEX (JII)

perdagangan satu negara tertentu dan lainnya. Dalam globalisasi, goncangan yang terjadi dalam perekonomian suatu negara dapat menyebabkan dampak ekonomi pada negara lainnya yaitu ketika ekonomi domestik terintegrasi dengan ekonomi global, hal itu menjadikannya rentan terhadap segala gejolak dalam ekonomi global (Wahyudi dan Sani, 2014). Dalam ruang lingkup bisnis, variabel ekonomi makro mempengaruhi kenaikan atau penurunan dalam kinerja perusahaan, baik secara langsung maupun tidak langsung.

Demikian juga, Yusof dan Abdul Majid (2007) dalam Wahyudi dan Sani (2014) menyatakan bahwa kondisi pasar modal sebagai indikator utama untuk ekonomi suatu negara saling terkait dengan negara tersebut yakni kondisi makroekonominya. Dengan kata lain, saat kondisi makroekonomi suatu negara mengalami perubahan, investor menghitung dampaknya terhadap kinerja perusahaan di masa depan, dan kemudian membuat keputusan untuk membeli atau menjual saham yang mereka miliki (Wahyudi dan Sani, 2014). Investor akan mengkalkulasikan dampaknya baik positif maupun negatif yang nantinya akan mempengaruhi keputusan saham terkait (Samsul, 2006). Perilaku ini dapat memberikan hasil perubahan saham, dan akhirnya mempengaruhi indeks di pasar saham (Wahyudi dan Sani, 2014).

\section{METODE PENELITIAN}

\section{Pendekatan Penelitian}

Pendekatan penelitian ini menggunakan pendekatan penelitian kuantitatif, dimana metode ini melibatkan penelitian yang berupa angka-angka dan analisisnya menggunakan statistik dengan beranjak dari teori yang didukung oleh penelitian terdahulu yang relevan yang dapat digunakan sebagai hipotesis dalam suatu penelitian (Sugiyono, 2014). Penelitian ini mengkaji teori dan penelitian terdahulu yang relevan dengan persoalan yang sedang diteliti sehingga dapat membuat jawaban sementara (hipotesis) berdasarkan rumusan masalah penelitian yang ditetapkan.

\section{Definisi Operasional}

Variabel endogen dalam penelitian ini adalah harga saham. Sedangkan Variabel eksogen dalam penelitian ini terdiri dari inflasi (IF), Nilai Tukar (NT), harga minyak dunia (HMD), harga emas dunia (HED), Dow Jones Islamic Market Index (DJIM).

\section{Jenis dan Sumber Data}

Data yang digunakan dalam penelitian ini berbentuk time series. Datanya berupa closing price bulanan seluruh variabel dari Januari 2013 hingga Desember 2018 dengan jumlah pengamatan sebanyak 432. Adapun data yang dihimpun bersumber dari Bursa Efek Indonesia², Bank Indonesia ${ }^{3}$, Kementrian Perdagangan4, U.S Energy Information Administration 5 , Federal

\footnotetext{
${ }^{2}$ Data JII

${ }^{3}$ Data inflasi dan nilai tukar

${ }^{4}$ Data nilai tukar

${ }^{5}$ Data harga minyak dunia
} 
Rahmiyanti, et al/Jurnal Ekonomi Syariah Teori dan Terapan Vol. 6 No. 12 Desember 2019: 2381-2392; PENGARUH VARIABEL MAKROEKONOMI DAN INDEKS SAHAM INTERNASIONAL TERHADAP INDEKS SAHAM JAKARTA ISLAMIC INDEX (JII)

Reserve Bank6, Thomson Reuters 7 , Home of the Private Investor ${ }^{8}$.

\section{Teknik Analisis Data}

Teknik analisis yang digunakan dalam penelitian ini adalah Error Correction Model (ECM) yang digunakan untuk mengatasi masalah tidak stasionernya data pada data time series, Hal ini penting agar hasil regresi yang diperoleh tidak meragukan (regresi lancung / spurious regression) dikarenaka penggunaan data time series yang melibatkan jangka waktu yang lama. Data yang bersifat trend, cenderung mengalami regresi lancung dikarenakan variabel dependen dan variabel independen sama-sama menunjukkan kecendrungan untuk meningkat dengan bertambanya waktu (Muhammad, 2014).

Menurut Johansen dalam (Kurniawan, 2011) bahwa ECM memiliki kemampuan untuk mengetahui adanya hubungan dinamis jangka pendek. Suatu set variabel memiliki hubungan dinamis jangka panjang belum tentu memiliki hubungan dinamis jangka pendek. Penggunaan ECM dalam analisis ekonomi digunakan untuk menjelaskan mengapa pelaku ekonomi menghadapi adanya ketidakseimbangan (Widarjono, 2017).

\section{Hasil dan Pembahasan}

\section{Hasil Uji Stasioneritas}

Tabel 1 menjelaskan bahwa tidak semua variabel stasioner pada tingkat level. Pada penelitian ini menggunaakan $a=5 \%$. Variabel inflasi, dan Harga minyak dunia memiliki nilai PP t-statistik lebih besar daripada nilai Mac Kinnon Critical Valve yang memiliki arti bahwa variabel itu stasioner. Sedangkan variabel lainnya memiliki nilai PP t-statistik yang lebih kecil dari pada nilai Mac Kinnon Critical Value maka dari itu dinyatakan tidak stasioner.

Tabel 1.

Uji stasioner Tingkat Level

\begin{tabular}{|c|c|c|c|c|}
\hline & \multirow{2}{*}{$\begin{array}{c}\text { ADF } \\
\text { Statisti } \\
\mathbf{k}\end{array}$} & \multicolumn{3}{|c|}{ Mackinnon Critical Value } \\
\hline & & $1 \%$ & $5 \%$ & $10 \%$ \\
\hline \multirow[t]{3}{*}{$\mathrm{JI}$} & - & - & - & - \\
\hline & 2.2364 & 4.0925 & 3.4743 & 3.1644 \\
\hline & 82 & 47 & 63 & 99 \\
\hline \multirow[t]{3}{*}{$\mathrm{IF}$} & - & - & - & - \\
\hline & 3.6826 & 4.0945 & 3.4753 & 3.1650 \\
\hline & 43 & 50 & 05 & 46 \\
\hline \multirow[t]{3}{*}{ NT } & - & - & - & - \\
\hline & 2.3739 & 4.0925 & 3.4743 & 3.1644 \\
\hline & 73 & 47 & 63 & 99 \\
\hline $\mathrm{HM}$ & - & - & - & - \\
\hline \multirow[t]{2}{*}{ D } & 1.7223 & 4.0945 & 3.4753 & 3.1650 \\
\hline & 36 & 50 & 05 & 46 \\
\hline \multirow[t]{3}{*}{ HED } & - & - & - & - \\
\hline & 3.9982 & 4.0925 & 3.4743 & 3.1644 \\
\hline & 16 & 47 & 63 & 99 \\
\hline DJI & - & - & - & - \\
\hline \multirow[t]{2}{*}{$M$} & 1.9272 & 4.0925 & 3.4743 & 3.1644 \\
\hline & 10 & 47 & 63 & 99 \\
\hline
\end{tabular}

${ }^{6}$ Data harga emas dunia

${ }^{7}$ Data DJIM

${ }^{8}$ Data DJIM 
Rahmiyanti, et al/Jurnal Ekonomi Syariah Teori dan Terapan Vol. 6 No. 12 Desember 2019: 2381-2392; PENGARUH VARIABEL MAKROEKONOMI DAN INDEKS SAHAM INTERNASIONAL TERHADAP INDEKS SAHAM JAKARTA ISLAMIC INDEX (JII)

Secara umum bisa dikatakan bahwa jika data time series tidak stationer pada tingkat level tetapi menjadi stationer pada tingkat diferensi yang sama. Dengan kata lain uji kointegrasi hanya bisa dilakukan ketika data yang digunakan dalam penelitian berintegrasi pada derajat yang sama (Widarjono, 2017). Sehingga tahap selanjutnya dari uji stasioneritas yaitu uji pada tingkat first difference. Pada tingkat first difference variabel Jakarta Islamic Index, inflasi, nilai tukar, harga minyak dunia, harga emas dunia, tidak memiliki unit root dan dinyatakan stasioner.

Tabel 2.

Uji Stasioner Tingkat First Difference

\begin{tabular}{|c|c|c|c|c|}
\hline & \multirow{2}{*}{$\begin{array}{c}\text { ADF } \\
\text { Statistik }\end{array}$} & \multicolumn{3}{|c|}{ Mackinnon Critical Value } \\
\hline & & $1 \%$ & $5 \%$ & $10 \%$ \\
\hline JII & $\begin{array}{l}- \\
7.26773 \\
2\end{array}$ & $\begin{array}{l}- \\
4.09455 \\
0\end{array}$ & $\begin{array}{l}- \\
3.47530 \\
5\end{array}$ & $\begin{array}{l}- \\
3.16504 \\
6\end{array}$ \\
\hline IF & $\begin{array}{l}- \\
6.57021 \\
3\end{array}$ & $\begin{array}{l}- \\
4.09661 \\
4\end{array}$ & $\begin{array}{l}- \\
3.47627 \\
5\end{array}$ & $\begin{array}{l}- \\
3.16561 \\
0\end{array}$ \\
\hline NT & $\begin{array}{l}- \\
9.37636 \\
8\end{array}$ & $\begin{array}{l}- \\
4.09455 \\
0\end{array}$ & $\begin{array}{l}- \\
3.47530 \\
5\end{array}$ & $\begin{array}{l}- \\
3.16504 \\
6\end{array}$ \\
\hline $\mathrm{HM}$ & $\begin{array}{l}- \\
5.54119 \\
1\end{array}$ & $\begin{array}{l}- \\
4.09455 \\
0\end{array}$ & $\begin{array}{l}- \\
3.47530 \\
5\end{array}$ & $\begin{array}{l}- \\
3.16504 \\
6\end{array}$ \\
\hline $\mathrm{HE}$ & $\begin{array}{l}- \\
8.38550 \\
0\end{array}$ & $\begin{array}{l}- \\
4.09455 \\
0\end{array}$ & $\begin{array}{l}- \\
3.16504 \\
6\end{array}$ & $\begin{array}{l}- \\
3.16504 \\
6\end{array}$ \\
\hline $\begin{array}{l}\text { DJI } \\
\text { M }\end{array}$ & $\begin{array}{l}- \\
9.01944 \\
5\end{array}$ & $\begin{array}{l}- \\
4.09455 \\
0\end{array}$ & $\begin{array}{l}- \\
3.47530 \\
5\end{array}$ & $\begin{array}{l}- \\
3.16504 \\
6\end{array}$ \\
\hline
\end{tabular}

\section{Hasil Uji Lag Optimum}

Uji lag optimum digunakan sebagai syarat untuk menjalankan uji selanjutnya berdasarkan lag yang terpilih. Pemilihan lag optimal menentukan bagaimana penafsiran daripada penelitian yang dilakukan. lag optimal yang disarankan oleh eviews adalah lag 1 dengan adanya tanda bintang palig banyak di lag 1 yaitu pada kriteria nilai Schwarz Criteria (SC), Hannan Quinn Criterion ( $H Q$ ).

\section{Hasil Uj Kointegrasi}

Tujuan dari uji kointegrasi adalah untuk mengetahui vapakah ariabel-variabel dalam penelitian memiliki pergerakan yang sama dalam jangka panjang. Jika nilai trace static dan max-eigenvalues lebih besar dari critical value pada tingkat signifikansi $a=5 \%$ maka persamaan tersebut dikatakan terkointegrasi.

Tabel 3.

Uji Kointegrasi

\begin{tabular}{|c|c|c|c|c|}
\hline $\begin{array}{l}\text { Hypothesi } \\
\text { zed No. } \\
\text { Of CE(s) }\end{array}$ & $\begin{array}{l}\text { Eigenva } \\
\text { lue }\end{array}$ & $\begin{array}{l}\text { Trace } \\
\text { Statisti } \\
\quad c\end{array}$ & $\begin{array}{c}5 \% \\
\text { Critic } \\
\text { al } \\
\text { Value } \\
\end{array}$ & $\begin{array}{c}\text { Prob. } \\
* *\end{array}$ \\
\hline None* & $\begin{array}{c}44784 \\
4\end{array}$ & $\begin{array}{c}86.219 \\
63\end{array}$ & $\begin{array}{c}83.937 \\
12\end{array}$ & $\begin{array}{c}0.03 \\
39\end{array}$ \\
\hline At most 1 & $\begin{array}{c}0.19510 \\
1\end{array}$ & $\begin{array}{c}44.644 \\
92\end{array}$ & $\begin{array}{c}60.061 \\
41\end{array}$ & $\begin{array}{c}0.48 \\
90\end{array}$ \\
\hline At most 2 & $\begin{array}{c}0.17679 \\
7\end{array}$ & $\begin{array}{c}29.452 \\
21\end{array}$ & $\begin{array}{c}40.174 \\
93\end{array}$ & $\begin{array}{c}0.38 \\
36\end{array}$ \\
\hline At most 3 & $\begin{array}{c}0.16294 \\
2\end{array}$ & $\begin{array}{c}15.833 \\
57\end{array}$ & $\begin{array}{c}24.275 \\
96\end{array}$ & $\begin{array}{c}0.39 \\
17\end{array}$ \\
\hline At most 4 & $\begin{array}{c}0.04614 \\
2\end{array}$ & $\begin{array}{c}3.3832 \\
25\end{array}$ & $\begin{array}{c}12.320 \\
90\end{array}$ & $\begin{array}{c}0.79 \\
76\end{array}$ \\
\hline At most 5 & $\begin{array}{c}0.00109 \\
1\end{array}$ & $\begin{array}{c}0.0764 \\
16\end{array}$ & $\begin{array}{c}4.1299 \\
06\end{array}$ & $\begin{array}{c}0.82 \\
05\end{array}$ \\
\hline $\begin{array}{l}\text { Hypothesi } \\
\text { zed } \\
\text { No. Of } \\
\text { CE(s) }\end{array}$ & $\begin{array}{l}\text { Eigenva } \\
\text { lue }\end{array}$ & $\begin{array}{c}\text { Max- } \\
\text { Eigen } \\
\text { Statisti } \\
\quad C\end{array}$ & $\begin{array}{c}0.05 \\
\text { Critic } \\
\text { al } \\
\text { Value }\end{array}$ & $\begin{array}{c}\text { Prob } \\
* *\end{array}$ \\
\hline None* & 0.44784 & 41.574 & 36.630 & 0.01 \\
\hline
\end{tabular}


Rahmiyanti, et al/Jurnal Ekonomi Syariah Teori dan Terapan Vol. 6 No. 12 Desember 2019: 2381-2392; PENGARUH VARIABEL MAKROEKONOMI DAN INDEKS SAHAM INTERNASIONAL TERHADAP INDEKS SAHAM JAKARTA ISLAMIC INDEX (JII)

\begin{tabular}{|c|c|c|c|c|}
\hline & 4 & 71 & 19 & 22 \\
\hline \multirow{2}{*}{ At most 1 } & 0.19510 & 15.192 & 30.439 & 0.88 \\
& 1 & 71 & 61 & 67 \\
\hline \multirow{2}{*}{ At most 2 } & 0.17679 & 13.618 & 24.159 & 0.63 \\
& 7 & 64 & 21 & 63 \\
\hline \multirow{2}{*}{ At most 3 } & 0.16294 & 12.450 & 17.797 & 0.26 \\
& 2 & 34 & 30 & 53 \\
\hline \multirow{2}{*}{ At most 4 } & 0.04614 & 3.3068 & 11.224 & 0.73 \\
& 2 & 09 & 80 & 96 \\
\hline \multirow{2}{*}{ At most 5 } & 0.00109 & 0.0764 & 4.1299 & 0.82 \\
& 1 & 16 & 06 & 05 \\
\hline
\end{tabular}

\begin{tabular}{|c|c|c|c|}
\hline & 0.121591 & 1.07687 & Signifikan \\
\hline \multicolumn{4}{|c|}{ Jangka Penek } \\
\hline Variabel & Koefisien & $\begin{array}{c}\mathrm{t}- \\
\text { statistik }\end{array}$ & Keterangan \\
\hline CointEql & $\begin{array}{c}- \\
0.007113\end{array}$ & $\begin{array}{c}- \\
0.38833\end{array}$ & - \\
\hline $\mathrm{D}(\mathrm{Jll}(-1))$ & 0.047985 & 0.32708 & - \\
\hline$D(I F(-1))$ & $\begin{array}{c}- \\
5.033092\end{array}$ & 1.09651 & $\begin{array}{c}\text { Tidak } \\
\text { signifikan }\end{array}$ \\
\hline$D(N T(-1))$ & 0.002880 & 0.26512 & $\begin{array}{c}\text { Tidak } \\
\text { signifikan }\end{array}$ \\
\hline $\begin{array}{l}\mathrm{D}(\mathrm{HMD}(- \\
1))\end{array}$ & 0.391890 & $\begin{array}{c}- \\
0.62954\end{array}$ & $\begin{array}{c}\text { Tidak } \\
\text { signifikan }\end{array}$ \\
\hline $\begin{array}{l}\mathrm{D}(\mathrm{HED}(- \\
1))\end{array}$ & 0.084749 & 1.49731 & $\begin{array}{c}\text { Tidak } \\
\text { signifikan }\end{array}$ \\
\hline $\begin{array}{l}\text { D(DJIM(- } \\
1))\end{array}$ & 0.021934 & 0.62709 & $\begin{array}{c}\text { Tidak } \\
\text { signifikan }\end{array}$ \\
\hline
\end{tabular}

sebelumnya menunjukkan adanya kointegrasi yang menandakan bahwa penelitian bisa digunakan untuk melihat jangka pendek dari suatu variabel terhadap nilai jangka panjangnya.

Tabel 4.

Tabel Estimasi ECM

\begin{tabular}{|c|c|c|c|}
\hline \multicolumn{4}{|c|}{ Jangka Panjang } \\
\hline Variabel & Koefisien & $\begin{array}{c}\mathbf{t}- \\
\text { statistik }\end{array}$ & Keterangan \\
\hline$J \|(-1)$ & 1.000000 & - & - \\
\hline $\mathrm{IF}(-1)$ & 1.421945 & $\begin{array}{c}- \\
0.07389\end{array}$ & $\begin{array}{c}\text { Tidak } \\
\text { Signifikan }\end{array}$ \\
\hline NT(-1) & 0.104497 & 3.52525 & Signifikan \\
\hline $\operatorname{HMD}(-1)$ & 5.111318 & 2.90767 & Signifikan \\
\hline $\operatorname{HED}(-1)$ & $\begin{array}{c}- \\
1.586466\end{array}$ & $\begin{array}{c}- \\
8.34947\end{array}$ & Signifikan \\
\hline DJIM(-1) & - & - & Tidak \\
\hline
\end{tabular}

Selain jangka panjang, dalam tabel juga menunjukkan hasil estimasi ECM pada jangka pendek yang ditunjukkan melalui Cointal yang merupakan Error Correction Term (ECT) variabel dependen. Nilai parameter ECT bernilai negatif menunjukkan koreksi terhadap penyimpangan yang akan mengindikasikan adanya penyesuaian hubungn jangka pendek menuju hubungan jangka panjang dengan koreksi kesalahan sebesar -0.007113 , besaran angka tersebut menjelaskan untuk mencapai keseimbangan jangka panjang diperlukan koreksi kesalahan sebesar $-0.007113$ dan untuk periode selanjutnya akan lebih baik lagi sehingga kesalahan akan menjadi hilang. 
Rahmiyanti, et al/Jurnal Ekonomi Syariah Teori dan Terapan Vol. 6 No. 12 Desember 2019: 2381-2392; PENGARUH VARIABEL MAKROEKONOMI DAN INDEKS SAHAM INTERNASIONAL TERHADAP INDEKS SAHAM JAKARTA ISLAMIC INDEX (JII)

\section{Pembahasan}

\section{Pengaruh Inflasi Terhadap JII}

Hasil penelitian menunjukkan bahwa nilai inflasi tidak berpengaruh signifikan terhadap indeks saham yaitu JII. Artinya, ketika inflasi mengalami peningkatan akan menyebabkan JII meningkat namun tidak memiliki makna. Menurut Beik dan Fatmawati (2015), dengan hasil inflasi yang tidak signifikan terhadap indeks saham JII menunjukkan bahwa investor mengabaikan tingkat inflasi dalam mengambil keputusan berinvestasi.

Selama periode pengamatan, tingkat inflasi berada pada periode normal atau tidak dalam keadaan krisis sehingga tidak mempengaruhi investor untuk mempertimbangkannya dalam membuat keputusan untuk berinvestasi pada saham syariah. Terdapat faktor lain yang dapat mempengaruhi keputusan investor dalam berinvestasi pada saham syariah, seperti nilai tukar maupun harga minyak. Tingkat inflasi pada dasarnya merupakan variabel yang penting dan memiliki pengaruh besar terhadap perekonomian. Namun pasar modal berbasis syariah dinilai punya daya tahan lebih kuat terhadap guncangan ekonomi saat kondisi perekonomian domestik maupun global yang masih belum stabil, dikarenakan dalam pasar saham syariah tidak mengenal saham perbankan (Widyasa dan Worokinasih, 2018).

\section{Pengaruh Nilai Tukar Terhadap JII}

Hasil penelitian menunjukkan bahwa nilai tukar memiliki pengaruh yang signifikan terhadap JII. Dengan melemahnya nilai
tUkar IDR terhadap USD yang artinya nilai tukar dalam negeri yaitu IDR mengalami depresiasi, maka investor akan mengalihkan dananya ke luar negeri yang nantinya terjadi capital outflow. Capital outflow inilah yang menyebabkan investasi dalam negeri mengalami penurunan, salah satunya investasi pada saham sehingga harga saham pun mengalami penurunan (Beik \& Fatmawati, 2015).

Hal ini dapat dijelaskan berdasarkan penelitian Asmy, Rohilina, Hassama, dan Fouad (2010) yang menyatakan bahwa efek daripada depresiasi nilai tukar dapat menciptakan harapan dimasa depan dengan adanya kenaikan mata vang di negara lain yang dapat menyebabkan jatuhnya arus investasi ke negara lain. Penjelasan tersebut juga didukung oleh De Satis dan Gerard (1998) dalam Ftiti dan Hadhri (2019) yang menjelaskan bahwa berbagai investasi yang melibatkan pihak asing merupakan kombinasi dari investasi pihak asing dan investasi dalam negeri (domestik) yang menyesuaikan dengan nilai tukar masing-masing negara yang berhubungan. Oleh karena itu perubahan dari nilai tukar mencerminkan resiko mata vang bagi pemegang saham.

Efek penyesuaian portofolio yang dilakukan pemegang saham terjadi sebagai hasil dari harapan investor tentang kinerja saham di Amerika Serikat. Misalnya ketika ekonomi Amerika Serikat dalam kondisi yang baik relatif teradap negara lain, memicu investor untuk beralih investasi di negara asing yaitu saham di Amerika. Dimana hal 
Rahmiyanti, et al/Jurnal Ekonomi Syariah Teori dan Terapan Vol. 6 No. 12 Desember 2019: 2381-2392; PENGARUH VARIABEL MAKROEKONOMI DAN INDEKS SAHAM INTERNASIONAL TERHADAP INDEKS SAHAM JAKARTA ISLAMIC INDEX (JII)

tersebut justru memberikan tekanan terhadap harga saham sehingga harga saham dan nilai tukar memiliki hubungan yang terbalik (Kim, 2003).

\section{Pengaruh Harga Minyak Dunia Terhadap JII}

Hasil penelitian menunjukkan bahwa harga minyak dunia memiliki pengaruh yang signifikan terhadap JII. Dalam kondisi harga minyak internasional yang tinggi, impor minyak akan menambah biaya produksi dan selanjutnya berdampak pada kenaikan harga-harga lainnya. Menurut Miller dan Ratti (2009) dalam (Tuna, 2019) menjelaskan harga minyak dapat mempengaruhi harga saham dikarenakan harga minyak merupakan input penting dalam proses produksi, akibatnya apabila harga minyak mengalami perubahan maka perusahaan juga akan menyesuaikan dengan perubahan tersebut yang selanjutnya akan mempengaruhi kinerja perusahaan.

Keadaan tersebut mempengaruhi aktivitas saham dimana investasi menjadi tidak kondisif dipasar modal . Investor akan bereaksi terhadap peluang/ ancaman peningkatan/ penurunan laba perusahaan pada tempat mereka berinvestasi maupun ingin berinvestasi pada perusahaan tersebut (Le dan Chang, 2014). Sehigga minyak memainkan peran pentig dalam menciptakan tekanan pada indeks pasar saham.

\section{Pengaruh Harga Emas Terhadap JII}

Hasil penelitian menunjukkan bahwa nilai harga emas dunia berpengaruh signifikan terhadap JII. Hasil tersebut berbeda dengan hipotesis yang sudah ditetapkan sebelumnya yaitu harga emas dunia berpengaruh negatif terhadap harga saham. berdasarkan hasil penelitian yang telah dilakukan sebelumnya menunjukkan hasil yang berbeda yaitu berpengaruh positif terhadap indeks saham JII. Menurut Le dan Chang (2014) menyatakan hubungan positif antara harga emas dan indeks saham menunjukkan bahwa pada kenytaannya kapanpun seseorang memiliki likuiditas yang cukup, pasar emas dan saham cenderung berjalan beriringan. Karena itu, berinvestasi dalam emas tidak menawarkan manfaat diversifikasi portofolio kepada investor (Singhal, Choudhary, dan Biswal, 2019).

Hubungan positif antara keduanya menunjukkan ketika harga emas mengalami peningkatan maupun penurunan, maka indeks saham akan merespon sama dengan harga emas. Hal tersebut dikarenakan data kedua variabel dalam periode penelitian ini mengalami penurunan seiring dengan perekonomian Indonesia yang sedang mangalami penurunan. Perkembangan produk domestik bruto di Indonesia 2010 2018 pada Gambar 4.8 yang memperlihatkan penurunan perekonomian Indonesia melalui tingkat PDB yang terus menurun dari kisaran 6\% ditahun 2012 kemudian menurun hingga 5\% ditahun 2018. Pada saat yang sama, indeks saham JII mengalami penurunan begitu juga dengan harga emas. Maka pada saat itu juga investor lebih memilih beralih pada investasi lainnya karena pada saat itu juga harga emas mengalami penurunan (Purnamasari \& 
Rahmiyanti, et al/Jurnal Ekonomi Syariah Teori dan Terapan Vol. 6 No. 12 Desember 2019: 2381-2392; PENGARUH VARIABEL MAKROEKONOMI DAN INDEKS SAHAM INTERNASIONAL TERHADAP INDEKS SAHAM JAKARTA ISLAMIC INDEX (JII)

Sukmana, 2016). Sehingga akhirnya memiliki hubungan yang positif.

\section{Pengaruh DJIM Terhadap JII}

Hasil penelitian menunjukkan bahwa

nilai Dow Jones Islamic Market tidak berpengaruh signifikan terhadap indeks saham yaitu JII. Hasil penelitian ini sejalan dengan penelitian yang telah dilakukan oleh (Beik \& Fatmawati, 2015) yang membuktikan bahwa Dow Jones Islamic Market tidak memiliki pengaruh yang signifikan terhadap JII. Artinya, ketika Dow Jones Islamic market mengalami peningkatan akan menyebabkan JII meningkat namun tidak memiliki makna.

Berdasarkan penelitian yang dilakukan oleh Beik \& Wardhana (2011) menunjukkan bahwa pasar modal Indonesia tidak terintegrasi dengan negara manapun, hal tersebut berbeda dengan hipotesis yang telah disusun sebelumnya. Dimana teori sebelumnya berdasarkan pada adanya integrasi antar negara akan memicu pergerakan yang sama untuk indeks yang dijadikan acuan, khususnya antara JII dengan DJIM.

Kemugkinan dari hasil tidak signifikan dikarenakan kapitalisasi pasar dari JII sangat jauh bila dibandingkan dengan DJIM. Perkembangan kapitalisasi DJIM dikutip melalui Islamic Financial Services Industry Stability Report pada tahun 2015 sebesar USD 22,1 triliun dari jumlah 2756 saham yang kemudian ditahun 2016 mengalami penurunan menjadi USD 23,2 triliun dari jumlah 2,653 saham. Sedangkan untuk JII dikutip melalui laporan statistik saham OJK, pada tahun 2015 kapitalisasi JII sebesar 1.737.290,98 milyar dan kemudian ditahun 2016 sebesar $2.041 .070,80$ milyar.

Perbedaan kapitalisasi yang jauh mengindikasikan bahwa JII relatif lebih stabil dibandingkan DJIM mengingat cakupan JII sebatas 30 saham sedangkan DJIM mencakup lebih dari 2000 saham. Sehingga apabila DJIM dijadikan acuanpun, perbandingan keduanya sangat jauh. Dengan hasil ini, seharusnya pemerintah maupun pihak pasar modal harus mengambil langkah yang lebih penting dalam mempromosikan Indeks saham JII antar negara sebagai jalan untuk menarik investor berinvestasi pada saham JII (Beik \& Fatmawati, 2015).

\section{SIMPULAN}

Berdasarkan ulasan hasil penelitian dan pembahasan tentang pengaruh dari inflasi, nilai tukar, harga minyak dunia, harga emas dunia dan DJIM terhadap Jakarta Islamic Index periode 2013 - 2018, simpulannya adalah dari semua variabel yang ada hanya inflasi yang tidak berpengaruh signifikan. Pada penelitian ini, masih memiliki banyak kekurangan, maka saran untuk penelitian kedepannya adalah peneliti bisa menerapkan periode sebelem, selamal, dan sesudah krisis untuk mendapatkan hasil yang lebih beragam, serta menambahkan variabel makro lainnya. Kemudian kedepannya investor muslim diharapkan akan lebih banyak berinvestasi pada instrumen syariah guna memperoleh manfaatnya dan sekaligus 
Rahmiyanti, et al/Jurnal Ekonomi Syariah Teori dan Terapan Vol. 6 No. 12 Desember 2019: 2381-2392; PENGARUH VARIABEL MAKROEKONOMI DAN INDEKS SAHAM INTERNASIONAL TERHADAP INDEKS SAHAM JAKARTA ISLAMIC INDEX (JII)

membantu perkembangan pasar momdal syariah di Indonesia.

\section{DAFTAR PUSTAKA}

Asmy, M., Rohilina, W., Hassama, A., \& Fouad, M. (2010). Effects of Macroeconomic Variables on Stock Prices in Malaysia: An Approach of Error Correction Model. Mpra, (20970), 1-33.

Beik, I. S., \& Fatmawati, S. W. (2015). Pengaruh Indeks Harga Saham Syariah Internasional Dan Variabel Makro Ekonomi Terhadap Jakarta Islamic Index. Al-lqtishad: Journal of Islamic Economics, 6(2).

Beik, I. S., \& Wardhana, W. (2011). The Relationship between Jakarta Islamic Index and Other Selected Markets : Evidence from Impulse Response Function. October, (2), 1-14.

Bursa Efek Indonesia. (2019). Jakarta Islamic Index.

Ftiti, Z., \& Hadhri, S. (2019). Can economic policy uncertainty, oil prices, and investor sentiment predict Islamic stock returns? A multi-scale perspective. Pacific Basin Finance Journal, 53, 40-55.

Kim, K. H. (2003). Dollar exchange rate and stock price: Evidence from multivariate cointegration and error correction model. Review of Financial Economics, 12 (3), 301-313.

Kurniawan, A. (2011). Analisis Hubungan Perubahan Price Earning Ration (PER), Devidend Yield dan Harga Saham Pada Perusahaan Manufaktur yang Listing di Bursa Efek Indonesia. (m).

Muhammad, M. (2014). Kointegrasi dan estimasi ecm pada data time series. Jurnal Konvergensi, 4 (1), 41-51.

Purnamasari, D., \& Sukmana, R. (2016). Pengaruh Harga emas Dunia, Harga Minyak Mentah Dunia, dan Indeks Produksi Industri terhadap Indeks Saham di Jakarta Islamic Index (JII) dalam Jangka Panjang dan Jangka Pendek. Jurnal Ekonomi Syariah Teori Dan Terapan, 515-530.

Samsul, M. (2006). Pasar Modal dan Manajemen Portofolio. Jakarta: Erlangga.

Singhal, S., Choudhary, S., \& Biswal, P. C. (2019). Return and volatility linkages among International crude oil price, gold price, exchange rate and stock markets: Evidence from Mexico. Resources Policy, 60lSeptember 2018), 255-261.

Sugiyono. (2014). Metode Penelitian Kuantitatif, Kualitatif, dan R\&D. Bandung: ALFABETA CV.

Tuna, G. (2019). Interaction between precious metals price and Islamic stock markets. International Journal of Islamic and Middle Eastern Finance and Management, 12 (1), 96114.

Wahyudi, I., \& Sani, G. A. (2014). Interdependence between Islamic capital market and money market: Evidence from Indonesia. Borsa Istanbul Review, 14(1), 32-47. 
Rahmiyanti, et al/Jurnal Ekonomi Syariah Teori dan Terapan Vol. 6 No. 12 Desember 2019: 2381-2392; PENGARUH VARIABEL MAKROEKONOMI DAN INDEKS SAHAM INTERNASIONAL TERHADAP INDEKS SAHAM JAKARTA ISLAMIC INDEX (JII)

Widarjono, A. (2017). Ekonometrika Pengantar dan Aplikasinya disertai Panduan Eviews. Yogyakarta: UPP STIM YKPN.

Widyasa, V. I. A., \& Worokinasih, S. (2018). Pengaruh Tingkat Inflasi, Nilai Tukar Rupiah, dan Tingkat Suku Bunga Terhadap Indeks Saham Syariah
Indonesia (ISSI) (Studi Pada Saham Syariah Yang Terdaftar Di Bursa Efek Indonesia Periode 2013-2017). Jurnal Administrasi Bisnis (JAB), 60(1), 119128.

Yuliana, I. (2010). Investasi Produk Keuangan Syariah. Malang: UIN-MALIKI PRESS. 